Research Article

\title{
Compatibility of Azospirillum brasilense with Pesticides Used for Treatment of Maize Seeds
}

\author{
Mariana S. Santos $\left(\mathbb{D},,^{1,2}\right.$ Artur B. L. Rondina $\left(\mathbb{D},{ }^{1}\right.$ Marco A. Nogueira $\left(\mathbb{D},{ }^{1}\right.$ \\ and Mariangela Hungria $\mathbb{I D}^{1,2}$ \\ ${ }^{1}$ Embrapa Soja, C.P. 231, Londrina, 86001-970 Paraná, Brazil \\ ${ }^{2}$ Department of Biochemistry and Biotechnology, State University of Londrina, C.P. 10.011, Londrina, 86057-970 Paraná, Brazil
}

Correspondence should be addressed to Mariangela Hungria; mariangela.hungria@embrapa.br

Received 2 April 2020; Accepted 8 June 2020; Published 10 July 2020

Academic Editor: Giuseppe Comi

Copyright (C) 2020 Mariana S. Santos et al. This is an open access article distributed under the Creative Commons Attribution License, which permits unrestricted use, distribution, and reproduction in any medium, provided the original work is properly cited.

\begin{abstract}
Seed treatment with chemical pesticides is commonly used as an initial plant protection procedure against pests and diseases. However, the use of such chemicals may impair the survival and performance of beneficial microorganisms introduced via inoculants, such as the plant growth-promoting bacterium Azospirillum brasilense. We assessed the compatibility between the most common pesticide used in Brazil for the treatment of maize seeds, composed of two fungicides, and one insecticide, with the commercial strains Ab-V5 and Ab-V6 of A. brasilense, and evaluated the impacts on initial plant development. The toxicity of the pesticide to $A$. brasilense was confirmed, with an increase in cell mortality after only 24 hours of exposure in vitro. Seed germination and seedling growth were not affected neither by the A. brasilense nor by the pesticide. However, under greenhouse conditions, the pesticide affected root volume and dry weight and root-hair incidence, but the toxicity was alleviated by the inoculation with $A$. brasilense for the root volume and root-hair incidence parameters. In maize seeds inoculated with $A$. brasilense, the pesticide negatively affected the number of branches, root-hair incidence, and root-hair length. Therefore, new inoculant formulations with cell protectors and the development of compatible pesticides should be searched to guarantee the benefits of inoculation with plant growth-promoting bacteria.
\end{abstract}

\section{Introduction}

Global population reached 7.6 billion people in 2017 and, according to the predictions, will increase to 11.2 billion by 2100 [1]. In this context, it is necessary to produce more food but also to search for production strategies resulting in minimum environmental impact. The inoculation of crops with plant growth-promoting bacteria (PGPB), especially those that can contribute to the reduction of chemical fertilizers usage, attends to these concepts of agricultural sustainability [2].

Several benefits have been attributed to the inoculation with $A$. brasilense, including the supply of $\mathrm{N}$ by the biological nitrogen fixation (BNF) process $[3,4]$, stimulation of root growth [5,6], phosphate solubilization [7], and increased tolerance to abiotic $[8,9]$ and biotic $[10]$ stresses. In the case of the Brazilian commercial strains of A. brasilense Ab-V5 and $\mathrm{Ab}-\mathrm{V} 6$, the main effects have been attributed to the production of phytohormones $[3,4]$.

The use of fungicides and insecticides for seed treatment has been broadly employed in Brazil, with maize representing the second crop that receives more pesticides, after soybean (Glycine max (L.) Merr.) [11]. However, the use of inoculants with $A$. brasilense for the maize crop is also impressively increasing, for example, in Brazil, from zero to 7 million doses per year ${ }^{-1}$ in less than a decade, and agrochemicals could affect bacterial survival and plant growth. For example, in the Bradyrhizobium-soybean symbiosis, the incompatibility with pesticides may cause lower nodulation and, consequently, lower BNF rates [12, 13].

There is still little information about the effects of pesticides used for the treatment of maize seeds on $A$. 
brasilense survival and plant growth. As seed treatment is widespread in the maize cropping, studies on the impact of pesticides in A. brasilense are necessary to understand the effects on the bacterium and on the mechanisms of plant growth promotion.

\section{Materials and Methods}

2.1. Microorganisms, Fungicides, and Insecticides. The experiments were performed with Azospirillum brasilense strains Ab-V5 (=CNPSo 2083) and Ab-V6 (=CNPSo 2084). The strains are deposited at the "Diazotrophic and Plant Growth-Promoting Bacteria Culture Collection of Embrapa Soja” (WFCC Collection \#1213, WDCM Collection \#1054) in Londrina, State of Paraná, Brazil. These two strains have been broadly used in the production of commercial inoculants for the maize crop in Brazil since 2009 [3]. Depending on the analysis, the strains were cultured together or separately.

The pesticide used was Standak ${ }^{\mathrm{TM}}$ Top (BASF), broadly employed for the treatment of maize seeds. It consists of a mixture of one insecticide (Fipronil 25\%) and two fungicides (pyraclostrobin 2.5\% and thiophanate-methyl 22.5\%). The recommended dose is of $2 \mathrm{~mL}$ per $\mathrm{kg}$ of maize seeds.

\subsection{Recovery of A. brasilense from Maize Seeds Treated with} Pesticides. The recovery of A. brasilense strains Ab-V5 and $\mathrm{Ab}-\mathrm{V} 6$ from maize seeds treated with the pesticide was based on the method described by Santos et al. [14]. The inoculum was prepared in the modified liquid DYGS medium (composed of glucose, $2 \mathrm{~g}$; malic acid, $2 \mathrm{~g}$; Bacto peptone, 1.5 g; yeast extract, $2 \mathrm{~g} ; \mathrm{K}_{2} \mathrm{HPO}_{4}, 0.5 \mathrm{~g} ; \mathrm{MgSO}_{4} \cdot 7 \mathrm{H}_{2} \mathrm{O}, 0.5 \mathrm{~g}$; and glutamic acid, $1.5 \mathrm{~g} ; \mathrm{pH} 6.8$ ), incubated at $28^{\circ} \mathrm{C}$, and shook at $120 \mathrm{rpm}$ until the cell concentration of $10^{8} \mathrm{CFU} \cdot \mathrm{mL}^{-1}$. Seeds were previously hydrated in distilled sterile water for $2 \mathrm{~h}$ and treated with Standak ${ }^{\mathrm{TM}}$ Top at the dose of $2 \mathrm{~mL} \cdot \mathrm{kg}^{-1}$, or left untreated; both treatments were left to dry at room temperature for $2 \mathrm{~h}$. The inocula were diluted in distilled sterile water prior to seed inoculation $(1: 2, \mathrm{v} / \mathrm{v})$. Treated and nontreated seeds were then inoculated with $A$. brasilense strains $\mathrm{Ab}-\mathrm{V} 5$ and $\mathrm{Ab}-\mathrm{V} 6$, applied to the seeds at the rate of $5 \mathrm{~mL} \cdot \mathrm{kg}^{-1}$, corresponding to $10^{5}$ cells seed ${ }^{-1}$. Cell recovery from seeds was performed 30 minutes and $24 \mathrm{~h}$ after inoculation.

Three biological samples of 100 seeds each were transferred to sterile Erlenmeyer flasks containing $100 \mathrm{~mL}$ of sterile water with Tween $80\left(0.4 \mathrm{~mL} \cdot \mathrm{L}^{-1}\right)$. The flasks were submitted to horizontal agitation at $150 \mathrm{rpm}$ for $30 \mathrm{~min}$, resulting in the dilution $10^{\circ}$. One-milliliter aliquot of the recovery sample was then transferred to a sterile flask with $9 \mathrm{~mL}$ of $0.85 \%$ physiological solution, resulting in the $10^{-1}$ dilution. The flask was shaken on a vortex. The process was repeated until the $10^{-4}$ dilution was obtained. $100 \mu \mathrm{L}$ aliquot of each replicate of each dilution was spread into Rojo Congo (RC) solid culture medium [15] [composed of, per L, DL-malic acid, $5 \mathrm{~g}$; yeast extract, $0.5 \mathrm{~g} ; \mathrm{K}_{2} \mathrm{HPO}_{4}, 0.5 \mathrm{~g}$; $\mathrm{MgSO}_{4} \cdot 7 \mathrm{H}_{2} \mathrm{O}, 0.2 \mathrm{~g} ; \mathrm{NaCl}, 0.1 \mathrm{~g} ; \mathrm{KOH}, 4.8 \mathrm{~g} ; \mathrm{FeCl}_{3} .6 \mathrm{H}_{2} \mathrm{O}$, $0.015 \mathrm{~g}$; Congo Red, $15 \mathrm{~mL}$ (solution at $0.25 \mathrm{mg} 100 \mathrm{~mL}$ ); and agar, $20 \mathrm{~g} ; \mathrm{pH} 7.0$ ], with vancomycin $\left(0.1 \mathrm{~g} \cdot \mathrm{L}^{-1}\right)$ to avoid seeds' contaminants, followed by incubation for 5 days at $28 \pm 2^{\circ} \mathrm{C}$. The recovery of viable cells was based on the counting of colony-forming units (CFU). Each treatment was performed in triplicate.

The experiment was performed on a completely randomized design (CRD), and the data were submitted to the analysis of variance (ANOVA), followed by the comparison of means by Tukey's test at $p<0.05$ with the statistical software.

2.3. Seed Germination and Seedling Vigor of Maize Treated with Pesticides and Inoculated with A. brasilense. In order to evaluate the compatibility between the pesticide and the $A$. brasilense inoculant, as well as the effects on seed germination and initial growth of maize seedlings, maize seeds (Agroceres AG9010 PRO VT) were surface-disinfected and, depending on the treatment, were treated or not with Standak ${ }^{\mathrm{TM}}$ Top and with a mixture of strains Ab-V5 and AbV6 of A. brasilense. Four treatments were evaluated: NPNI (control with no pesticide, no inoculant); WPNI (with pesticide, no inoculant); NPWI (no pesticide, with inoculant); and WPWI (with pesticide, with inoculant). Each treatment consisted of three replicates, each with 12 seeds and the experiment was performed in a completely randomized design (CRD).

Seed surface disinfection was performed in ethanol $70 \%$ for $1 \mathrm{~min}$, hypochlorite $10 \%$ for $5 \mathrm{~min}$ and then washed in sterile distilled water five times. First, the seeds of the treatments with the pesticide were treated with Standak ${ }^{\mathrm{TM}}$ Top at a rate of $2 \mathrm{~mL} \cdot \mathrm{kg}^{-1}$ of seeds, as recommended by the manufacturer. Seeds were allowed to dry at room temperature for $2 \mathrm{~h}$.

For each treatment, a tray was disinfected with $10 \%$ hypochlorite and then left under laminar flow UV light for $20 \mathrm{~min}$. Following, three Germitest papers (JProlab ${ }^{\circledR}$ ) previously autoclaved were placed in the tray and moistened with sterile water. The seeds were scattered over two papers, forming 12 columns. Following, the seeds of the treatments with inoculation each received the inoculant of $A$. brasilense at a final concentration of $10^{5}$ cells of $A$. brasilense per seed and the third paper was placed over the seeds. The papers were rolled up; their ends were tied with elastic bands and incubated in a seed germinator DeLeo ${ }^{\circledR}$ at $25^{\circ} \mathrm{C}$ and $45 \pm 5 \%$ of relative air humidity for seven days.

After this period, seed germination rate and seedling vigor parameters, including total length of the seedlings (from the tip of the primary root to the top of the primary leaf), the length of the shoot, and the length of the main root axis, were evaluated with the aid of a ruler with a graduation in $\mathrm{mm}$ [16]. The average length was obtained by summing the measurements taken from each normal seedling at each repetition and then dividing by the number of normal seedlings measured.

The experiment was performed in a completely randomized design (CRD) with the treatments arranged in a factorial scheme $(2 \times 2)$, involving presence/absence of pesticide and presence/absence of inoculation. Statistical 
analysis was performed using the RBIO statistical software. Data obtained were evaluated for normality and variance homogeneity, followed by the analysis of variance (ANOVA) by Tukey's test at $5 \%$ probability.

2.4. Greenhouse Experiment. A greenhouse experiment was carried out to assess the effects of the pesticide used together with the inoculant on the initial development and root morphology of maize. Plants were grown in modified Leonard jars [17] containing $750 \mathrm{~cm}^{3}$ of sterilized substrate, consisting of a mixture of sand and pulverized coal $(3: 1$, $\mathrm{v} / \mathrm{v})$, containing sterile nutrient solution with all macronutrients and micronutrients [18]. The experiment consisted of the same four different treatments described before: NPNI, WPNI, NPWI, and WPWI. The experimental design was performed in a completely randomized design (CRD) with treatments arranged in a factorial scheme $(2 \times 2)$, involving presence/absence of pesticide and presence/absence of inoculation with $A$. brasilense, with five replicates.

Maize seeds (Agroceres AG-9010) were surface-sterilized with $70 \%$ ethanol and 3\% sodium hypochlorite [17]. For the treatments WPNI and WPWI, the seeds were treated with Standak $^{\mathrm{TM}}$ Top ( $2 \mathrm{~mL}$ per $\mathrm{kg}$ of maize seeds) and left to dry for two hours. For the treatments NPNI and NPWI, this step was not performed. The seeds of the treatments NPWI and WPWI were inoculated with a mixture of Ab-V5 and Ab-V6, ensuring a concentration of $10^{5}$ cells seed ${ }^{-1}$. Three seeds were sown and thinned to one plant per jar four days after emergence. Nutrient solution was applied as needed, and the temperature and humidity at the greenhouse were controlled by means of air conditioners $\left(25^{\circ} \pm 5^{\circ} \mathrm{C}\right.$ and $80 \pm 5 \%$, respectively).

Thirty-eight days after emergence, plant height $(\mathrm{cm})$ and culm diameter $(\mathrm{mm})$ were assessed with the aid of a ruler and digital caliper. Plants were harvested and the shoots were separated from the roots. The shoots were oven-dried at $60^{\circ} \mathrm{C}$ until constant dry weight. The roots were washed with running water until completely clean. Approximately, $1 \mathrm{~g}$ of fresh roots from each sample was separated and stained in methylene blue (1\%) solution for $1 \mathrm{~min}$ and washed again in water and scanned with Epson Perfection V370 Photo ${ }^{\circledR}$ for further morphological analysis. The remaining roots were oven-dried under the same conditions as the shoot.

The scanned root images were analyzed using GiA Roots $^{\circledR}$ software to assess specific length $\left(\mathrm{m} \cdot \mathrm{g}^{-1}\right)$, weighted average diameter $(\mathrm{mm})$, tissue density, and volume $\left(\mathrm{cm}^{3}\right)$. The value determined in each scanned root fragment was estimated for the total fresh mass of the root system.

Approximately, $0.1 \mathrm{~g}$ of fresh fine roots was obtained from each sample, stored in FAA solution (90\% ethanol $70 \%$, $5 \%$ formaldehyde, and 5\% acetic acid) and used for assessment of root-hair incidence, root-hair length, and number of root branches. The number of root branches was counted using a stereomicroscope at $30 \mathrm{X}$ magnification to estimate the number of lateral roots. Root-hair incidence was determined by the presence or absence of root hairs on 150 fine-root intersections using the gridline method [19]. Root-hair length was assessed measuring 50 root hairs in fine-root segments using a microscope at $100 \mathrm{X}$ magnification with an ocular micrometer.

The dataset was first evaluated for normality and variance homogeneity. Means were compared using the analysis of variance (ANOVA) followed by Tukey's test at 5\% probability. All analyses were performed in the software $\mathrm{RBIO}^{\circledR}$.

\section{Results and Discussion}

The number of $A$. brasilense cells recovered from maize seeds significantly decreased after $24 \mathrm{~h}$ of inoculation for both strains, with or without pesticide (Figure 1). In addition, strain Ab-V5, but not Ab-V6, was significantly affected by the seed treatment with the pesticide after $24 \mathrm{~h}$, with a drastic decrease from $4.56 \times 10^{5} \mathrm{CFU}$ seed $^{-1}$ in the day of inoculation to $4.37 \times 10^{2} \mathrm{CFU}$ seed $^{-1}$ after $24 \mathrm{~h}$. Santos et al. [14] also reported drastic cell mortality of $A$. brasilense after $24 \mathrm{~h}$ of exposure to another pesticide (carbendazim + thiram). Pereira et al. [20] observed similar results when exposing these same strains to pesticide-coated (metalaxyl$\mathrm{m}+$ fludioxonil + thiamethoxam + abamectin + Peridiam) maize seeds; after $12 \mathrm{~h}$ of exposure, the authors observed a cell survival rate of $65.87 \%$ in seeds without pesticide and of $13.56 \%$ when treated with the pesticide.

It is important to comment that farmers usually treat their seeds with pesticides and inoculants and sowing may take several hours or even days. Our results indicate that $A$. brasilense is a very sensitive bacterium, with poor survival capacity in maize seed surface, even in the absence of pesticides. Therefore, cell protectors in inoculant formulations, speed of sowing, and other strategies should be searched to guarantee the performance of elite strains of $A$. brasilense.

Neither the inoculation of $A$. brasilense nor the seed treatment with the pesticide affected significantly seed germination rate, ranging from 86.10 to $91.66 \%$ (Table 1). Similar results were observed by Vogel and Fey [21]. Dartora et al. [22] also found no effect of the fungicide fludioxonilmetalaxyl and of $A$. brasilense on the percentage of germination of maize seeds. Similarly, in wheat (Triticum aestivum), Muraneto et al. [23] observed no differences in germination of seeds treated with fungicide, insecticide, and A. brasilense.

For the seed vigor parameters, there was also no interaction between the factors (pesticide and inoculation). However, the best results for total length $(36.93 \mathrm{~cm})$, root length $(22.66 \mathrm{~cm})$, and shoot length $(13.26 \mathrm{~cm})$ were observed in the treatment without pesticide and inoculation (NPWI) treatment. Some farmers have concerns about the inoculation with Azospirillum affecting seed germination and seedling growth. Therefore, our data confirm that there was no negative effect caused by strains Ab-V5 and Ab-V6 that could affect plant emergence.

Plant height varied between 67 and $71 \mathrm{~cm}$, culm diameter between 9.6 and $10.7 \mathrm{~mm}$, and shoot dry weight between 2.5 and $3 \mathrm{~g}$, with no significant interaction between the inoculation and the pesticide for any of the parameters (Table 2). Although without statistical difference, the lowest height, 
$\mathrm{Ab}-\mathrm{V} 5$

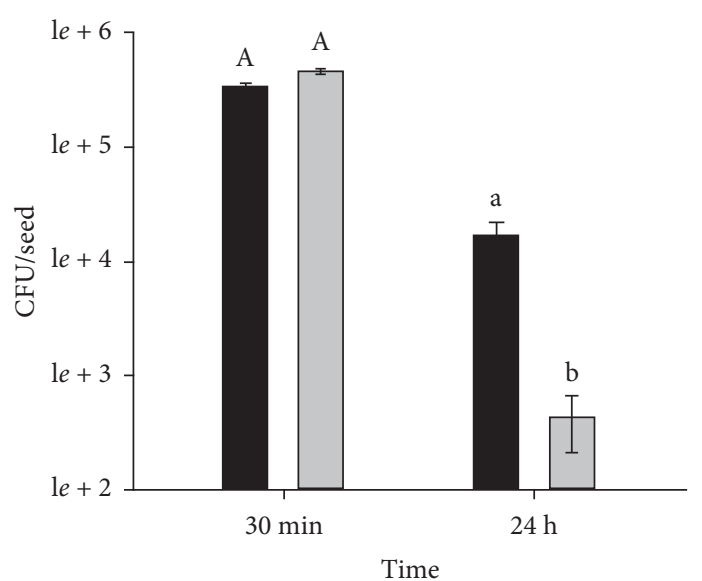

NP

WP

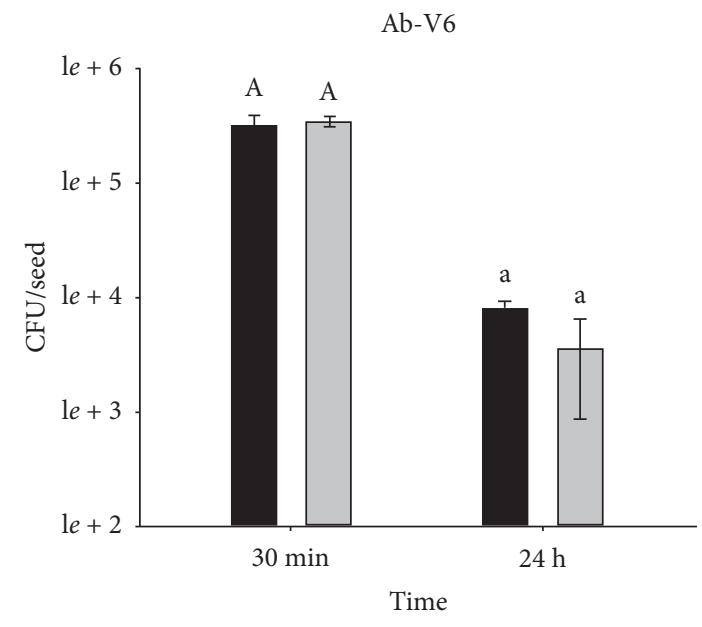

NP

WP

(a)

(b)

FIGURE 1: Recovery of Azospirillum brasilense cells (expressed in CFU seed ${ }^{-1}$ ) from maize seeds treated (WP) or not (NP) with pesticide 30 minutes and $24 \mathrm{~h}$ after inoculation. Data represent the means of three biological replicates, each with three technical replicates $(n=9)$, and when followed by the same letter do not differ from each other by Tukey's test at $p<0.05$. (a) Ab-V5; (b) Ab-V6.

TABLE 1: Germination rate and initial growth of maize seedlings whose seeds were treated or not with pesticide and were inoculated or not with Azospirillum brasilense strains Ab-V5 and Ab-V6.

\begin{tabular}{lcccc}
\hline Treatments & Germination rate $(\%)$ & Total length $(\mathrm{cm})$ & Root length $(\mathrm{cm})$ & Shoot length $(\mathrm{cm})$ \\
\hline NPNI & $88.88 \mathrm{Aa}$ & $33.34 \mathrm{Aa}$ & $21.42 \mathrm{Aa}$ & $10.91 \mathrm{Aa}$ \\
WPNI & $88.88 \mathrm{Aa}$ & $34.15 \mathrm{Aa}$ & $20.85 \mathrm{Aa}$ & $12.30 \mathrm{Aa}$ \\
NPWI & $86.10 \mathrm{Aa}$ & $36.93 \mathrm{Aa}$ & $22.66 \mathrm{Aa}$ & $13.26 \mathrm{Aa}$ \\
WPWI & $91.66 \mathrm{Aa}$ & $35.03 \mathrm{Aa}$ & $21.80 \mathrm{Aa}$ & 0.47 \\
$p$-value & 0.24 & 0.90 & 4.86 & 0.84 \\
CV $(\%)$ & 14.06 & 4.41 & $\mathrm{Aa}$ & 8.97 \\
\hline
\end{tabular}

Data represent the means of five replicates and when followed by the same letter do not differ from each other by Tukey's test at $p<0.05$. Uppercase letters compare means within the same pesticide condition (WP: with pesticide and NP: no pesticide) and lowercase letters compare means within the same inoculation condition (WI: with inoculation and NI: no inoculation).

TABLE 2: Shoot attributes of maize whose seeds were treated or not with pesticide and were inoculated or not with Azospirillum brasilense strains Ab-V5 and Ab-V6.

\begin{tabular}{lccc}
\hline Treatments & Plant height $(\mathrm{cm})$ & Culm diameter $(\mathrm{mm})$ & Shoot dry mass $(\mathrm{g})$ \\
\hline NPNI & $71.0 \mathrm{Aa}$ & $10.4 \mathrm{Aa}$ & $3.0 \mathrm{Aa}$ \\
WPNI & $67.0 \mathrm{Aa}$ & $9.6 \mathrm{Aa}$ & $2.5 \mathrm{Aa}$ \\
NPWI & $67.7 \mathrm{Aa}$ & $10.0 \mathrm{Aa}$ & $2.7 \mathrm{Aa}$ \\
WPWI & $71.0 \mathrm{Aa}$ & $10.7 \mathrm{Aa}$ & $2.8 \mathrm{Aa}$ \\
$p$-value & 0.702 & 0.835 & 0.0867 \\
CV $(\%)$ & $5.94 \%$ & $9.82 \%$ & $12.84 \%$ \\
\hline
\end{tabular}

Means of five replicates followed by the same letter do not differ from each other by Tukey's test at $p<0.05$. Uppercase letters compare means within the same pesticide condition (WP: with pesticide and NP: no pesticide) and lowercase letters compare means within the same inoculation condition (WI: with inoculation and NI: no inoculation).

culm diameter, and shoot dry mass were observed in the treatment with pesticide and no inoculation (WPNI).

Even when noninoculated maize seeds were treated with the pesticide, there was a decrease in root volume (Figure 2(a)), root dry weight (Figure 2(b)), and root-hair number (Figure 2(c)); therefore, the stress caused in plants by pesticides can reduce the efficiency of the root system in acquiring water and nutrient resources and, consequently, plant growth. Bonea and Bonciu [24] investigated the cytological and genotoxic effects induced by the fungicide Royal Flo, with thiram in its composition, and verified that the fungicide reduced the mitotic index of the root meristem. 


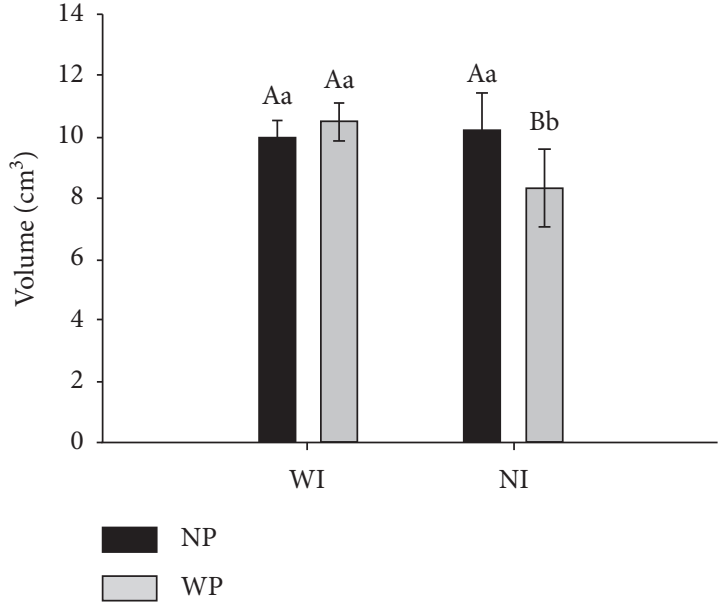

(a)

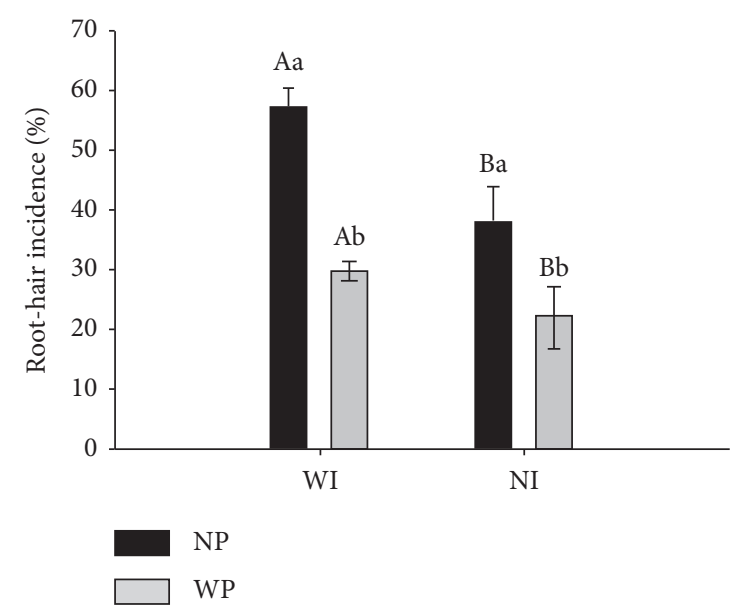

(c)

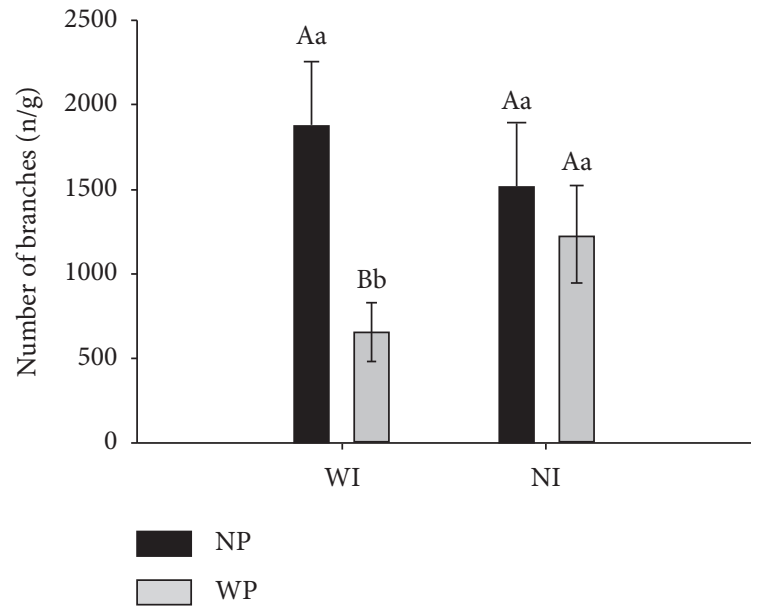

(e)

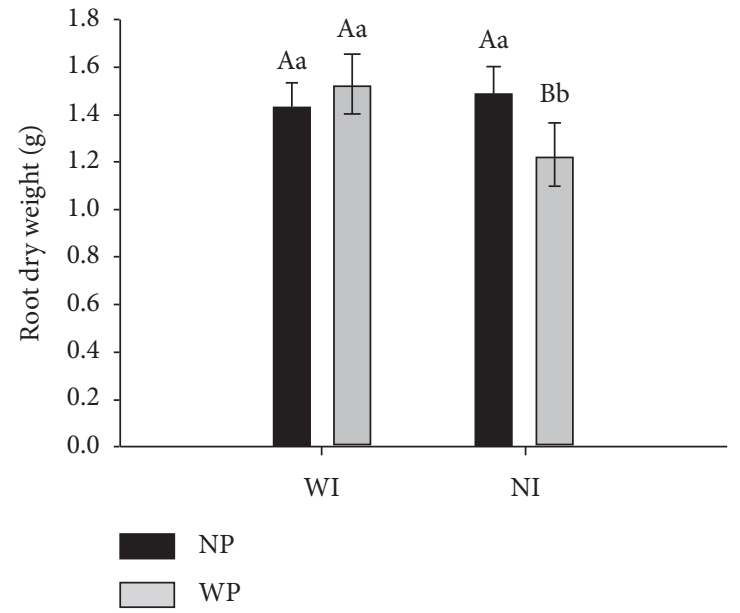

(b)

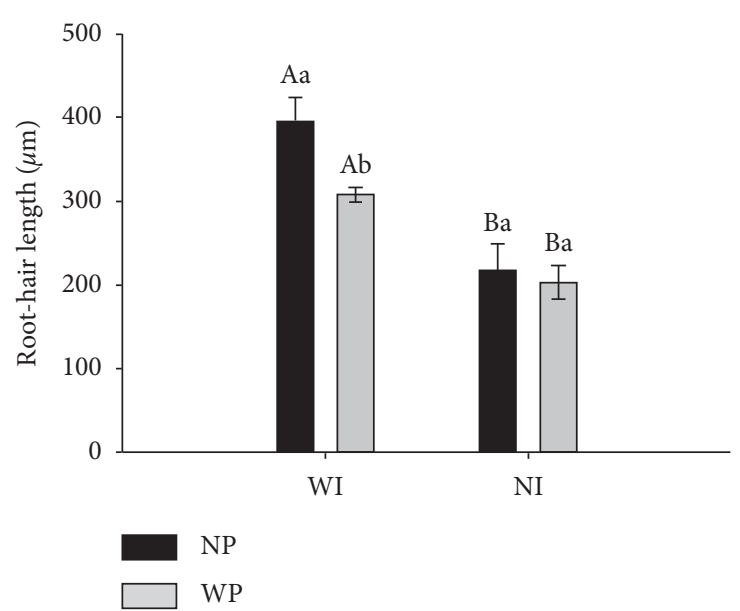

(d)

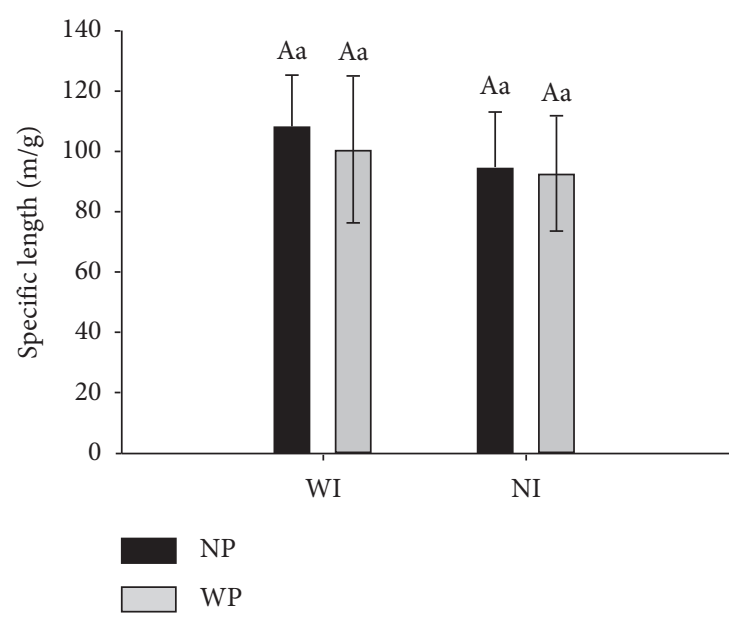

(f)

FIgUre 2: Continued. 


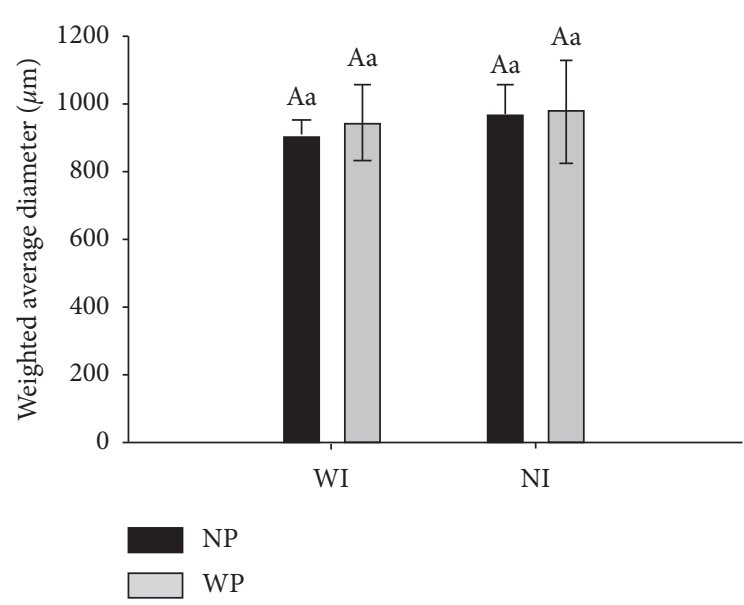

(g)

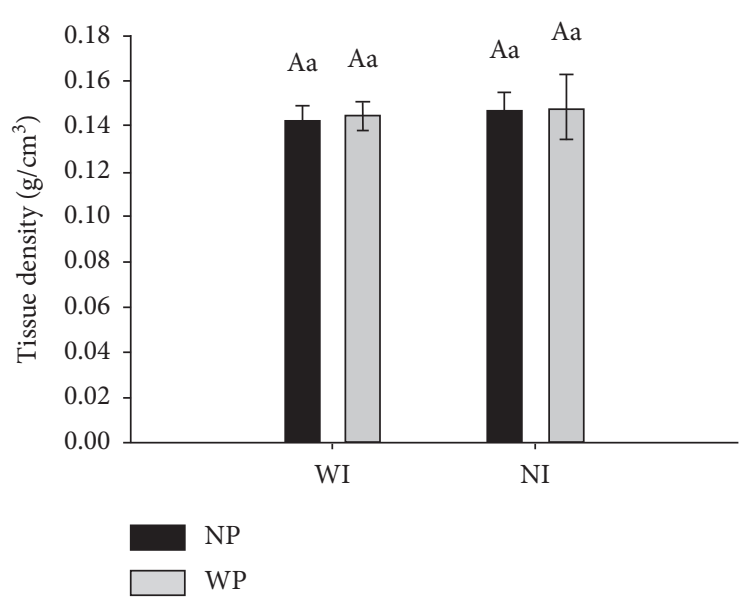

(h)

Figure 2: (a) Volume; (b) root dry weight; (c) root hair incidence; (d) root hair length; (e) number of branches; (f) specific length; (g) weighted average diameter; and (h) tissue density of roots of maize whose seeds were treated or not with pesticide and were inoculated or not with Azospirillum brasilense strains Ab-V5 + Ab-V6. Plants were grown under greenhouse conditions for 38 days. Data represent the means of five replicates $(n=5)$ and when followed by the same letter do not differ from each other by Tukey's test at $p<0.05$. Uppercase letters compare means within the same pesticide condition (WP: with pesticide and NP: no pesticide) and lowercase letters compare means within the same inoculation condition (WI: with inoculation and NI: no inoculation). Vertical bars represent the standard deviation.

In our study, we showed that inoculation with $A$. brasilense helped to mitigate the toxic effects caused by the pesticide on root volume and root dry weight.

The main mechanism by which strains Ab-V5 and AbV6 of A. brasilense promote plant growth is by the production of auxins that stimulate root development $[4,9]$. The auxins are important modulators of cell division, acting on the differentiation and elongation of the root apex, on the initiation and development of secondary roots, and on the development of the vascular system [25]. Indeed, inoculation with Azospirillum leads to lateral root promotion [26], helping plant development and increasing the ability to acquire water and mineral nutrients from soil [27]. One of the most pronounced effects of Azospirillum inoculation on root morphology is the proliferation of root hairs, thin extensions of root epidermal cells that occur mainly near the apexes of stretching roots $[27,28]$. In our study, considering the seeds not treated with the pesticide, the main impact of inoculation with $A$. brasilense was on root-hair incidence (Figure 2(c)) and root-hair length (Figure 2(d)), which are very important properties for the uptake of water and nutrients [27]. However, in the presence of the pesticide, the benefits of inoculation were impaired for these two parameters and also for the number of branches per gram of root (Figure 2(e)).

The increase of root-hair incidence due to inoculation with Azospirillum sp. has been reported in other cultures as pearl millet (Pennisetum americanum L.) [29], wheat [30, 31], rice (Oryza sativa cv.) [32], burr medic (Medicago polymorpha L.) [33], alfalfa (Medicago sativa) [34], and tomato (Lycopersicon esculentum Mill.) $[35,36]$.

Recently, the impact of inoculation with $A$. brasilense has also been described by Rondina et al. [37] who studied the morphology of soybean roots inoculated with different treatments and observed that inoculation with Bradyrhizobium spp. together with A. brasilense (Ab-V5 and Ab-V6) increased specific root length, root-hair length, and the number of root branches compared to the single inoculation with Bradyrhizobium spp. The authors also reported that the presence of $A$. brasilense inoculated together with Bradyrhizobium spp. was determinant for the increase in the percentage of root length with diameter $<0.50 \mathrm{~mm}$.

Facing the benefits that can be achieved by the inoculation with $A$. brasilense, particularly with strains Ab-V5 and Ab-V6 [3, 4, 9, 28, 38], nowadays used in more than 7 million doses of inoculants commercialized per year in Brazil, it was mandatory to verify if the treatment of maize seeds with pesticides, broadly adopted by the farmers (e.g., [11]), was compatible with the bacteria. Some of the root parameters evaluated, such as specific length (Figure 2(f)), weighted average diameter (Figure $2(\mathrm{~g})$ ), and tissue density (Figure 2(h)), were not affected by the pesticide, neither in inoculated nor in noninoculated plants. However, other parameters such as root-hair incidence (Figure 2(c)), root volume (Figure 2(a)), and root dry weight (Figure 2(b)) were decreased even in noninoculated plants. Noteworthy, for these last two parameters, the inhibition caused by the pesticide was alleviated by the inoculation with $A$. brasilense, highlighting that the bacterium may play a key role in the mitigation of the abiotic stress, as pointed out before for other abiotic stresses, such as salinity $[4,9,36]$.

In addition, although we did not find differences in shoot parameters at this early evaluation of plant growth, we should consider that plants were growing under optimal controlled conditions of greenhouse, and that on the field the increase in number of hair and root-hair length in inoculated plants may both decrease the susceptibility to water stress conditions and improve maize nutrition, achieving 
good productivity results. This is even more important with the increasing number of episodes of drought reported with the global climate change.

\section{Conclusions}

We observed lower survival of $A$. brasilense in the presence of the pesticide Standak ${ }^{\mathrm{TM}}$ Top, with an increase in cell mortality after only $24 \mathrm{~h}$ of exposure. The treatment of maize seeds with Standak ${ }^{\mathrm{TM}}$ Top conferred toxic effects on plants, interfering with their development. Consequently, the known benefits of maize inoculation with $A$. brasilense (e.g., $[3,9,28])$, especially on cell division, differentiation, and elongation of roots, may be impaired by the seed treatment with pesticides. It is important to search for innovative inoculants containing cell protectors (e.g., [39, 40]), or to develop more compatible pesticides, so that the expected benefits of inoculation with plant growth-promoting bacteria can be obtained.

\section{Data Availability}

The data are included in the manuscript. Data with all replicates can be available from the corresponding author upon request.

\section{Conflicts of Interest}

The authors declare that there are no conflicts of interest regarding the publication of this paper.

\section{Acknowledgments}

M. S. S. acknowledges a Ph.D. fellowship from Araucaria Foundation in support to the Scientific and Technological Development of the State of Paraná, and A. B. L. R. acknowledges a postdoctoral fellowship from CNPq. M. A. N and $\mathrm{M} . \mathrm{H}$. are also research fellows of $\mathrm{CNPq}$ (Brazilian National Research Council for Science and Technology). This study was funded by INCT-Plant Growth-Promoting Microorganisms for Agricultural Sustainability and Environmental Responsibility (CNPq (465133/2014-2), Fundação Araucária (STI 043/2019), and CAPES), Embrapa, and CNPq-Universal (400468/2016-6).

\section{References}

[1] United Nations, "Department of economic and social affairs, population division. World population prospects: the 2017 revision. key findings and advance tables," in Proceedings of the Working Paper No. ESA/P/WP/248, New York, NY, USA, 2017.

[2] G. Kaschuk and M. Hungria, "Diversity and importance of diazotrophic bacteria to agricultural sustainability in the tropics," in Diversity and Benefits of Microorganisms from the Tropics, J. de Azevedo and M. Quecine, Eds., Springer International, New York, NY, USA, pp. 269-292, 2017.

[3] M. Hungria, R. J. Campo, E. M. Souza, and F. O. Pedrosa, "Inoculation with selected strains of Azospirillum brasilense and A. lipoferum improves yields of maize and wheat in Brazil," Plant and Soil, vol. 331, no. 1-2, pp. 413-425, 2010.
[4] J. Fukami, E. J. Ollero, M. Megías, and M. Hungria, "Phytohormones and induction of plant-stress tolerance and defense genes by seed and foliar inoculation with Azospirillum brasilense cells and metabolites promote maize growth," $A M B$ Express, vol. 7, pp. 1-13, 2017.

[5] L. Lin, Z. Li, C. Hu et al., "Plant growth-promoting nitrogenfixing enterobacteria are in association with sugarcane plants growing in guangxi, China," Microbes and Environments, vol. 27, no. 4, pp. 391-398, 2012.

[6] C. Santi, D. Bogusz, and C. Franche, "Biological nitrogen fixation in non-legume plants," Annals of Botany, vol. 111, no. 5, pp. 743-767, 2013.

[7] H. Rodriguez, T. Gonzalez, I. Goire, and Y. Bashan, "Gluconic acid production and phosphate solubilization by the plant growth-promoting bacterium Azospirillum spp," Naturwissenschaften, vol. 91, no. 11, pp. 552-555, 2004.

[8] D. Bulgarelli, K. Schlaeppi, S. Spaepen, E. V. L. Van Themaat, and P. Schulze-Lefert, "Structure and functions of the bacterial microbiota of plants," Annual Review of Plant Biology, vol. 64, no. 1, pp. 807-838, 2013.

[9] J. Fukami, P. Cerezini, and M. Hungria, "Azospirillum: benefits that go far beyond biological nitrogen fixation," $A M B$ Express, vol. 8, pp. 1-12, 2018.

[10] O. S. Correa, A. M. Romero, M. A. Soria, and M. De Estrada, "Azospirillum brasilense-plant genotype interactions modify tomato response to bacterial diseases, and root and foliar microbial communities," in Azospirillum sp.: Cell Physiology, Plant Interactions and Agronomic Research in Argentina, F. D. Cassán and I. S. Garcia, Eds., pp. 85-94, Asociación Argentina de Microbiologia, Buenos Aires, Argentina, 2008.

[11] W. A. Pignati, F. A. N. d. S. e. Lima, S. S. d. Lara et al., "Distribuição espacial do uso de agrotóxicos no Brasil: uma ferramenta para a Vigilância em Saúde," Ciência \& Saúde Coletiva, vol. 22, no. 10, pp. 3281-3293, 2017.

[12] A. Osman, A. Sherif, A. Elhussein, and A. Mohamed, "Sensitivity of some nitrogen fixers and the target pest Fusarium oxysporum to fungicide thiram," Interdisciplinary Toxicology, vol. 5, no. 1, pp. 25-29, 2012.

[13] C. F. Vogel, L. Martinkoski, S. O. Jadoski, and R. Fey, "Efeitos da combinação de Azospirillum brasilense com fungicidas no desenvolvimento de trigo," Brazilian Journal of Applied Technology for Agriculture Science, vol. 8, pp. 73-80, 2015.

[14] M. S. Santos, T. F. Rodrigues, E. Ferreira, M. Megias, M. A. Nogueira, and M. Hungria, "Method for recovering and counting viable cells from maize seeds inoculated with Azospirillum brasilense," Journal of Pure and Applied Microbiology, vol. 14, no. 1, pp. 1-9, 2020.

[15] E. A. R. Cáceres, "Improved medium for isolation of Azospirillum spp," Applied and Environmental Microbiology, vol. 44, no. 4, pp. 990-991, 1982.

[16] F. C. Krzyzanowski, R. D. Vieira, and J. B. França Neto, Vigor de Sementes: Conceitos e Teste, Abrates, Londrina, Brazil, 1999.

[17] J. M. Vincent, "A manual for the practical study of rootnodule bacteria," in IBP Handbook, vol. 15, Blackwell, Oxford, UK, 1970.

[18] D. R. Hoagland and D. I. Arnon, The Water Culture Method for Growing Plants without Soils, California Agricultural Experimental Station, Berkeley, CA, USA, 1950.

[19] W. Zangaro, F. R. Nishidate, F. R. S. Camargo, G. G. Romagnoli, and J. Vandressen, "Relationships among arbuscular mycorrhizas, root morphology and seedling growth of tropical native woody species in southern Brazil," Journal of Tropical Ecology, vol. 21, no. 5, pp. 529-540, 2005. 
[20] L. C. Pereira, C. de Carvalho, A. K. Suzukawa et al., "Toxicity of seed-applied pesticides to Azospirillum spp.: an approach based on bacterial count in the maize rhizosphere," Seed Science and Technology, vol. 48, pp. 241-246, 2020.

[21] G. F. Vogel and R. Fey, “Azospirillum brasilense interaction effects with captan and thiodicarb on the initial growth of corn plants," Journal of Neotropical Agriculture, vol. 6, no. 3, pp. 53-59, 2019.

[22] J. Dartora, V. F. Guimarães, D. Marini, A. S. Pinto Júnior, L. M. Cruz, and R. Mensch, "Influência do Tratamento de Sementes no Desenvolvimento Inicial de Plântulas de Milho e Trigo Inoculados com Azospirillum brasilense," Scientia Agraria Paranaensis, vol. 12, no. 3, pp. 175-181, 2013.

[23] J. D. Muraneto, T. N. Martin, T. M. Muller, U. R. Nunes, G. B. Da Rosa, and L. F. T. Grando, "Compatibility of $A z o-$ spirillum brasilense with fungicide and insecticide and its effects on the physiological quality of wheat seeds," Semina: Ciências Agrárias, vol. 39, no. 2, pp. 855-864, 2018.

[24] D. Bonea and E. Bonciu, "Cytogenetic effects induced by the fungicide Royal Flo to maize (Zea mays L.)," Caryologia, vol. 70, no. 3, pp. 195-199, 2017.

[25] K. Ljung, "Auxin metabolism and homeostasis during plant development," Development, vol. 140, no. 5, pp. 943-950, 2013.

[26] A. Akbari, S. M Arab, H. A. Alikhani, I. Allahdadi, and M. H. Arzanesh, "Isolation and selection of indigenous Azospirillum spp. and the IAA of superior strains effects on wheat roots," World Journal of Agricultural Sciences, vol. 3, pp. 523-529, 2007.

[27] J. B. Reece, S. A. Wasserman, L. A. Urry, M. L. Cain, P. V. Minorsky, and R. B. Jackson, Biologia de Campbell, Artimed, Porto Alegre, Brazil, 2015.

[28] Y. Okon, C. Labandera-Gonzales, M. Lage, and P. Lage, "Agronomic applications of azospirillum and other PGPR," in Biological Nitrogen Fixation, F. J. Bruijn, Ed., John Wiley \& Sons, Hoboken, NJ, USA, pp. 921-933, 2015.

[29] T. M. Tien, M. H. Gaskins, and D. H. Hubbell, "Plant growth substances produced by Azospirillum brasilense and their effect on the growth of pearl millet (Pennisetum americanum L.) $\dagger$," Applied and Environmental Microbiology, vol. 37, no. 5, pp. 1016-1024, 1979.

[30] D. G. Patriquin, J. Döbereiner, and D. K. Jain, "Sites and processes of association between diazotrophs and grasses," Canadian Journal of Microbiology, vol. 29, no. 8, pp. 900-915, 1983.

[31] S. Dobbelaere, A. Croonenborghs, A. Thys, A. Vande Broek, and J. Vanderleyden, "Phytostimulatory effect of Azospirillum brasilense wild type and mutant strains altered in IAA production on wheat," Plant and Soil, vol. 212, no. 2, pp. 153-162, 1999.

[32] T. E.-S. E.-D. Radwan, Z. K. Mohamed, and V. M. Reis, "Efeito da inoculação de Azospirillum e Herbaspirillum na produção de compostos indólicos em plântulas de milho e arroz," Pesquisa Agropecuária Brasileira, vol. 39, no. 10, pp. 987-994, 2004.

[33] E. Yahalom, A. Dovrat, Y. Okon, and H. Czsnek, "Effect of inoculation with Azospirillum brasilense strain CD and Rhizobium on the root morphology of burr medic (Medicago Polymorpha L.)," Israel Journal of Botany, vol. 40, pp. 155-164, 1991.

[34] R. Itzigsohn, Y. Kapulnik, Y. Okon, and A. Dovrat, "Physiological and morphological aspects of interactions between Rhizobium meliloti and alfalfa (Medicago sativa) in association with Azospirillum brasilense," Canadian Journal of Microbiology, vol. 39, no. 6, pp. 610-615, 1993.

[35] R. Hadas and Y. Okon, "Effect of Azospirillum brasilense inoculation on root development and respiration on tomato seedlings," Biology and Fertility of Soils, vol. 5, pp. 241-247, 1987.

[36] C. M. Ribaudo, E. M. Krumpholz, F. D. Cassán, R. Bottini, M. L. Cantore, and J. A. Curá, “Azospirillum sp. promotes root hair development in tomato plants through a mechanism that involves ethylene," Journal of Plant Growth Regulation, vol. 25, no. 2, pp. 175-185, 2006.

[37] A. B. L. Rondina, A. W. Dos Sanzovo, G. S. Guimarães, J. R. Wendling, M. A. Nogueira, and M. Hungria, "Changes is root morphological traits in soybean co-inoculated with Bradyrhizobium spp. and Azospirillum brasilense or treated with A. Brasilense exudates," Biology and Fertility of Soils, vol. 56, no. 4, pp. 537-549, 2020.

[38] J. Fukami, C. De La Osa, F. J. Ollero, M. Megías, and M. Hungria, "Co-inoculation of maize with Azospirillum brasilense and Rhizobium tropici as a strategy to mitigate salinity stress," Functional Plant Biology, vol. 45, no. 3, pp. 328-339, 2018.

[39] M. S. Santos, M. Hungria, and M. A. Nogueira, "Production of PHB and biofilm by Azospirillum brasilense aiming at the development of liquid inoculants with high performance," African Journal of Biotechnology, vol. 16, pp. 1855-1862, 2017.

[40] M. S. Santos, M. A. Nogueira, and M. Hungria, "Microbial inoculants: reviewing the past, discussing the present and previewing an outstanding future for the use of beneficial bacteria in agriculture," AMB Express, vol. 9, pp. 1-22, 2019. 